\title{
Semen quality and biochemistry and blood antioxidant status in Mehraban rams supplemented with organic selenium alone or combined with organic chromium during the summer
}

\author{
Abbas farahavar ( $\nabla$ farahavar@gmail.com ) \\ Bu Ali Sina University https://orcid.org/0000-0002-0931-4060 \\ Amirhosein Mehranfrooz \\ Bu-Ali Sina University: Bu Ali Sina University \\ Ahmad Ahmadi \\ Bu-Ali Sina University: Bu Ali Sina University \\ Morteza Yavari \\ Bu-Ali Sina University: Bu Ali Sina University
}

Research Article

Keywords: Antioxidant, Chromium, Ram, Selenium, Semen quality

Posted Date: February 25th, 2022

DOI: https://doi.org/10.21203/rs.3.rs-1343818/v1

License: (c) (7) This work is licensed under a Creative Commons Attribution 4.0 International License. Read Full License 


\section{Abstract}

The effects of organic selenium (Se) alone or combined with organic chromium ( $\mathrm{Cr}$ ) on semen quality and metabolites and blood antioxidant status was evaluated during the summer in rams. Fourteen Mehraban rams (2-4 years, BSC 2.5-3.5, initial body weight $70.14 \mathrm{~kg}$ ) were divided in to four groups $(n=4)$ and two levels of $\mathrm{Se}(0$ and $0.6 \mathrm{mg} / \mathrm{ram} /$ day, inactive dry Se-yeast) were tested at two levels of $\mathrm{Cr}(0$ and $1 \mathrm{mg} / \mathrm{ram} /$ day, Cr-methionine) in a completely randomized design with $2 \times 2$ factorial layout for 60 days. Body weight changes and scrotal circumference (SC) were recorded fortnightly. Semen quality and metabolites, rams libido, spermatozoa motion characteristics, blood ferric reducing ability (FRAP) and thiobarbituric acid reactive substances (TBARS) were measured during the experiment. Body weight, dry mater intake and SC were not affected by treatments. Chromium alone increased FRAP, libido and sperm linearity and combined with Se increased spermatozoa viability, membrane integrity and decreased semen glucose and alkaline phosphatase activity ( $\mathrm{P} \leq 0.05)$. Main effect of $\mathrm{Cr}$ tended to increase EV $(P=0.095)$. Abnormal spermatozoa and TBARS decreased by $\mathrm{Cr}$, Se or by their combination. Selenium alone had higher sperm concentration compared to its combination with $\mathrm{Cr}(\mathrm{P} \leq 0.05)$. Average path velocity was numerically higher by $\mathrm{Se}$ alone and curvilinear velocity was lower by combined with $\mathrm{Cr}$, but the difference was not significant $(\mathrm{P}>0.05)$. In conclusion, $\mathrm{Cr}$ and $\mathrm{Se}$ supplementation of rams during the summer improved semen quality and blood antioxidant status. However, co-supplementation of $\mathrm{Cr}$ and $\mathrm{Se} \mathrm{had} \mathrm{no} \mathrm{more}$ additional effects on studied parameters.

\section{Introduction}

In the sheep industry, rams are crucial for profitable lamb production. Many factors influence the fertility of rams, including age, breed, nutrition, management, and environmental temperature (Ghorbankhani et al., 2015). In the non-breeding season, rams are usually fed at maintenance level therefore, approximately three months before the rams being exposed to the ewes; their nutrition and welfare require more attention to ensure maximum efficiency of sperm production. Regarding this issue, basal diet energy and protein content, some trace elements, especially zinc, selenium and cobalt, impact reproductive performance of rams profoundly (Kendall et al., 2000).

It is well demonstrated that trivalent chromium ( $\mathrm{Cr}$ ) potentiates insulin action by increasing the affinity of insulin receptors to insulin (Weksler-Zangen et al., 2012). Although Cr deficiency has not been demonstrated in farm animals, however, responses to $\mathrm{Cr}$ supplementation have been variable and most consistent in animals exposed to various stressors such as heat, cold, weaning and etc (Spears 2019). Usually, rams experience summer heat stress especially in tropical zones and extensively raised situations where management measures are not well implemented or may be less worthy of attention by breeders. In addition to summer heat stress, rams due to high sexual activity experience doubled stress during joining season. Temperature controlled studies demonstrated that ram fertility is reduced when mating occurs during the period 14 to 50 days post-heating (Van Wettere, et al., 2021). Besides, heat stress depletes antioxidant capacity and alters postabsorptive carbohydrate (basal and stimulated) metabolism, characterized primarily by increased basal insulin concentrations and insulin response to a glucose tolerance test (O'brien et al., 2010). Many scientific documents emphasize that selenium (Se) and $\mathrm{Cr}$ are a promising agent for combating the adverse effects of stress in animals and are strong antioxidants that prevents heat stress-induced lipid peroxidation, improves nutrient metabolism and promotes insulin action, thereby increasing farm animal productivity (Bin-Jumah, et al., 2020). It has been reported that dietary supplementation of $\mathrm{Se}$ or $\mathrm{Cr}$ alone or their co-supplementation improves animal production performance and relives negative effects of summer heat stress (Bin-Jumah, et al., 2020; Domínguez-Vara, et al., 2009). Recent findings suggest that dietary high Cr-methionine supplementation in summer-exposed lambs improves blood antioxidant status and feed to gain efficiency without adverse effects on lambs' health and metabolism (Seifalinasab et al., 2021). Accompanying these studies, Biswas et al., (2014) reported that 500 or $750 \mu \mathrm{g} / \mathrm{kg}$ Cr-picolinate in diet of adult male turkeys in summer improve sperm concentration, progressive motility and fertility.

Several studies have reported the beneficial effects of dietary supplementation of organic or inorganic forms of Se on semen characteristics in farm animals (Shi et al., 2010; Baiomy et al., 2009; Marai et al., 2009). In addition, an increasing amount of evidence shows that, the negative effects of elevated environmental temperature on semen quality and fertility can be relieved with antioxidants and Se supplementation (Hosny et al., 2020; Chauhan et al., 2014). Because of the effective role of $\mathrm{Cr}$ and Se in reducing the negative effects of heat stress and enhancement of antioxidant power, we were interested to test $\mathrm{Cr}$ and Se alone on their combination on ram semen quality and biochemical composition and blood antioxidant status during the summer. To the best of our knowledge, there were no reports on the effects of organic $\mathrm{Cr}$ alone or combined with Se on semen characteristics in rams during the summer. Therefore, the aim of this study was to evaluate the semen quality and its biochemical composition and blood antioxidant status in rams supplemented with organic Se alone or combined with organic $\mathrm{Cr}$ during the summer.

\section{Material And Methods}

\section{Acquisition of trace elements}


The organic form of chromium was chromium methionine (Cr-Met) with trade name of Availa ${ }^{\circ} \mathrm{Cr}$ (Zinpro, USA) containing 1\% Cr-Met and $0.1 \% \mathrm{Cr}$ and calcium carbonate as carrier. The used Se source was organic form of Se, an inactive yeast (Saccharomyces cerevisiae) enriched with organic Se with trade name of Selemax $2000 \AA$ (Biorigin, Brazil) containing $0.2 \%$ Se in the form of inactive dry yeast.

\section{Animal's management and experimental design}

The experiment was carried out from July 1 to September 22 at the university of Bu-Ali Sina research farm (Latitude: $48031^{/} 36$ // N; Longitude 3500 / 12 // E; Altitude 1694 m), Hamedan, Iran. Fourteen Mehraban rams (2-4 years old, with a body score of 2.5-3.5 and 70.14 $\mathrm{kg}$ in initial body weight) were treated orally with Albendazole and Levamisole ( $5 \mathrm{ml} / 50 \mathrm{~kg}$ body weight) before beginning of the experiment. Rams were transferred to individual holding pens and adapted to the basal diet (Table 1) for one week. Then, the rams were randomly divided in to four groups ( $\mathrm{n}=4)$ and two levels of organic Se (0 and $0.6 \mathrm{mg} / \mathrm{ram} /$ day) were tested at two levels of organic Cr (0 and $1 \mathrm{mg} /$ $\mathrm{ram} /$ day) in a completely randomized design with $2 \times 2$ factorial layout. Clean and refreshing water was provided ad libitum for all rams during the entire period. Availa ${ }^{\circledR} \mathrm{Cr}(1 \mathrm{~g} / \mathrm{ram} /$ day) was filled in to empty pill capsules and fed to rams with morning meal. Aqueous suspension of Selemax $2000 \AA\left(0.3 \mathrm{~g} / \mathrm{ram} /\right.$ day) was prepared by fresh $\mathrm{H}_{2} \mathrm{O}$ and drenched to rams with morning meal. The basal diet (Table 1) was balanced according to the NRC (2007), and offered to rams twice daily (8:00 am and 5:00 pm). The experiment lasted for 60 days. Feed intake and residuals were measured daily. Rams body weight and scrotal circumference (SC) were recorded every 2-week. Body weight changes, dry matter intake (DMI), total gain (TG) and average daily gain (ADG) were recorded. Blood sample was collected by jugular vein puncture before morning meal at 09:00 on days 30 and 60 of experiment. Sample of seminal plasma was prepared at the same time by centrifugation of collected semen for $10 \mathrm{~min}$ at $2500 \mathrm{~g}$.

\section{Chemical Analysis}

Samples of feed and residual mixtures (which was collected daily) were taken at the time of diet formulation and analyzed for dry matter (65 ${ }^{\circ} \mathrm{C}$ for $72 \mathrm{~h}$ ), ash (550 ${ }^{\circ} \mathrm{C}$ for $8 \mathrm{~h}$ ) and crud protein (Kjeldahl Method) according to the procedures of the association of official analytical chemists (AOAC, 1997). Neutral detergent fiber (NDF) and acid detergent fiber (ADF) were determined by Van Soest fiber analysis method (Van Soest et al., 1991). Metabolizable energy was estimated by using NRC (2007) equations. The Cr concentration of basal diet was analyzed using atomic absorption spectrophotometer method and Se concentration of the basal diet was determined using graphite furnace atomic absorption spectrometry (AOAC, 1997).

Seminal plasma biochemical composition and enzyme activities were measured by Pars-azmoon kits (Tehran, Iran) and spectrophotometer according to their instructions. Shortly, the enzymatic-colorimetric methods used by the kits for assessment of glucose, cholesterol and triglyceride. Photometric UV test, bromocresol green, photometric-biuret, cresolphthalein compelexone respectively were methods or reagents for measurement of phosphorus, albumin, total protein and calcium. International federation of clinical chemistry (IFCC) methods used for evaluation of alkaline phosphatese (ALP), aspartate aminotransferase (AST), alanin aminotransferase (ALT) enzymes activity.

Ferric reducing ability of plasma (FRAP) and thiobarbituric acid reactive substances (TBARS) were evaluated according to described methods in our previous study (Farahavar et al. 2020). Briefly, a ratio of 10: 1: 1 of acetate buffer $(300 \mathrm{mM}, \mathrm{pH}=3.6), 2,4,6$-tripyridylstriazine (TPTZ: $10 \mathrm{mM}$ in $40 \mathrm{mM} \mathrm{HCl})$ and $\mathrm{FeCl} 3(20 \mathrm{mM})$ solutions respectively were mixed and ferric reducing ability of $50 \mu \mathrm{l}$ of plasma was measured by evaluation of absorbance of the colored solution at $593 \mathrm{~nm}$. The intra-assay coefficient of variations was less than $10.5 \%$. Results were expressed as $\mu \mathrm{mol} \mathrm{Fe} \mathrm{F}^{2+}$ that reduced by $1 \mathrm{ml}$ plasma sample. For TBARS assay, in the first step, the protein content of plasma sample was precipitated by using trichloroacetylacetate $(20 \% \mathrm{~W} / \mathrm{V}$, in $0.6 \mathrm{M} \mathrm{HCl})$ and centrifugation for $15 \mathrm{~min}$ at $2000 \mathrm{~g}$. Thiobarbituric acid (TBA) reaction was performed by mixing $0.3 \mathrm{ml}$ of TBA $(0.12 \mathrm{M}$, in $0.26 \mathrm{M}$ Tris, $\mathrm{pH}=7)$ with prepared supernatant in the previous step and incubated in boiling water for $15 \mathrm{~min}$. The absorbance of pink colored solution was measured at $532 \mathrm{~nm}$. The concentration of TBARS was determined using its extinction coefficient $155 \mathrm{mM}^{-1} \mathrm{~cm}-1$. The intra-assay coefficient of variation for TBARS assay was less than $9.5 \%$. Results were expressed as $\mu \mathrm{mol}$ TBARS per $\mathrm{ml}$ plasma sample. All chemical analysis was performed in duplicate.

\section{Semen collection and evaluation}

During the experiment, rams were accustomed to semen collection by artificial vagina (AV) in which rams were exposed to a ewe was in estrus. Each ram were subjected to 2 false mounts before ejaculation to arouse the sexual desire. Length of reaction time (RT) was measured from the time the ram saw the stimulus until was ejaculated into the AV and considered as a measure of the ram libido (Fahey et al., 2012). After elapsing at least 47 days (time required to complete one cycle of spermatogenesis in ram) of feeding the $\mathrm{Cr}$ and Se supplements, semen was collected, 3 times at 08:00 to 10:00 and averaged as the final results. Collected samples immediately were evaluated for general characteristics (ejaculate volume (EV, $\mathrm{ml}$ ), concentration (Conc. $\times 10^{9} . \mathrm{ml}^{-1}$ ), semen vigor (SV, $0-5$ scale), sperm viability (Viab, \%), membrane integrity (MI, \%) and total abnormality (TA, \%)) according to a published procedure (Molinia et al., 1994). The 
EV was measured by scald collecting tubes. Sperm concentration was determined in duplicate using a neubauer hemocytometer and spectrophotometer (at wavelength of $550 \mathrm{~nm}$ ) after dilution with distilled water (1:200) (Anzar, et al., 2009). TSE was calculated by multiplying EV by Conc. Percentage of sperm viability and abnormal morphology was determined by using eosin-nigrosin staining and counting 200 sperm cell under a light microscope and $400 \mathrm{X}$ magnification (Molinia et al., 1994). The hypo-osmotic swelling test (HOST) was performed to evaluate membrane integrity by incubating $5 \mu \mathrm{l}$ of fresh semen with $500 \mu \mathrm{l}$ of a $100 \mathrm{mOsm}$ HOS pre-warmed solution ( $0.49 \%$ sodium citrate dehydrate $\mathrm{w} / \mathrm{v}$ and fructose $0.9 \% \mathrm{w} / \mathrm{v}$ ) in $37^{\circ} \mathrm{C}$ for $30 \mathrm{~min}$ (Molinia et al., 1994). Sperm kinematic features and motion characteristics were measured by using CASA (computer-assisted sperm analysis system, Video Test-Sperm 3.1, St, Petersburg, Russia) system, digital color microscope camera (Mshot MD50-T, USB3.0, China), phase-contrast microscope (Labomed LX400 Microscopes, USA) equipped with warm stage set at $37^{\circ} \mathrm{C}$. Pre-warmed microscope slide was loaded with diluted sample $(7 \mu$ l, diluted in ratio of 1:200 with trisfructose-citric acid extender) and covered with cover slip glass $(18 \times 18 \mathrm{~mm})$ and ten microscopic fields were recorded at $200 \mathrm{X}$ magnifications. The following variables were analyzed by CASA according to WHO standards for humans: Total motility (TM, \%), fast progressive motility (FPM, \%), straight-line velocity (VSL, $\mu \mathrm{m} / \mathrm{s})$, curvilinear velocity (VCL, $\mu \mathrm{m} / \mathrm{s})$, average path velocity (VAP, $\mu \mathrm{m} / \mathrm{s})$, amplitude of lateral head displacement (ALH, \%), STR: straightness (VSL/VAP $\times 100)$ as the linearity of the average path, LIN: sperm linearity (VSL/VCL $\times 100)$ as a measure of a curvilinear path, WOB: wobble $(\mathrm{VAP} / \mathrm{VCL} \times 100)$ oscillation measure of the actual path about the average path, BCF: beat cross frequency, MAD: mean angular displacement (degrees).

\section{Statistical analyses}

The normal distribution of residuals of data sets were examined using Shapiro-Wilk test and were log-transformed (if needed) prior to ANOVA to satisfy the assumptions of normality and equal variances for residuals of the model. Semen quality parameters and RT as well as CASA detected sperm motility and kinematic features were analyzed by completely randomized design (CRD) using GLM procedure of SAS software (version 9.4, SAS Institute Inc, Cary, NC, USA) with the following model:

$\mathrm{Y}_{\mathrm{ijl}}=\mu+\mathrm{Cr}_{\mathrm{i}}+\mathrm{Se}_{\mathrm{j}}+\mathrm{CrSe}_{\mathrm{ij}}+\mathbb{\nabla}_{\mathrm{ij}}$,

Where $Y$ is the dependent variable, $\mu$ is the overall mean, $\mathrm{Cr}_{i}$ is independent effect of $\mathrm{Cr}$ levels, $\mathrm{Se}_{\mathrm{j}}$ is independent effect of Se levels, $\mathrm{CrSe}_{\mathrm{ij}}$ is interaction of $\mathrm{Cr} \times \mathrm{Se}$ and $\mathbb{\Xi}_{\mathrm{ijl}}$ is experimental error. Results are presented as mean \pm S.E.M.

Data sets of body weight changes, DMI, TG, ADG and SC as well as seminal plasma biochemical composition, FRAP and TBARS concentrations on days 30 and 60 of the experiment were analyzed using multi-factorial analysis of variance (ANOVA) for repeated measures (PROC GLM) of SAS software with the following model:

$Y i j k f x=\mu+\mathrm{Cr}_{i}+\mathrm{Se}_{j}+\mathrm{CrSe}_{i j}+\mathrm{T}_{\mathrm{K}}+\mathrm{CrT}_{f}+\mathrm{SeT}_{\mathrm{x}}+\mathrm{CrSeT}_{\mathrm{fx}}+\mathrm{EA} \mathrm{ijkfx}+\mathrm{EB} \mathrm{ijkfx}$,

Where $\mathrm{Y}$ is the dependent variable, $\mu$ is the overall mean, $\mathrm{Cr}_{\mathrm{i}}$ is independent effect of $\mathrm{Cr}$ levels, $\mathrm{Se}_{\mathrm{j}}$ is independent effect of $\mathrm{Se}$ levels, $\mathrm{CrSe}_{\mathrm{ij}}$ is interaction of $\mathrm{Cr}$ and $\mathrm{Se}, \mathrm{T}_{k}$ is fixed effect of time, $\mathrm{CrT}_{\mathrm{f}}$ is interaction of $\mathrm{Cr}$ and time in, $\mathrm{SeT}_{\mathrm{x}}$ interaction of time and $\mathrm{Se}, \mathrm{CrSeT}_{\mathrm{fx}}$ is interaction of $\mathrm{Cr}$, Se and time, $\mathrm{EA}_{\mathrm{ijkfx}}$ is main error and $\mathrm{EB} \mathrm{ijkfx}$ is minor error. Results are presented as Mean \pm S.E.M. wherever a significant interaction between Se and $\mathrm{Cr}$ was found, the comparison of the main effects was considered unauthorized due to statistical considerations and no comparison of the main effects was performed. Differences were considered to be statistically significant when $P \leq 0.05$.

\section{Results}

\section{Body weight and SC changes and dry mater intake}

There were not effects of time on final BW, TG, ADG, DMI and SC; in addition, interaction between treatment and time (treat $\times$ time) was not significant. Thus, overall results are presented in Table 2 for the above mentioned parameters. Final BW, TG, DMI, ADG and SC were not affected by Se or $\mathrm{Cr}$ supplementation and their interaction was not significant.

\section{Semen characteristics}

Results of dietary supplementation of $\mathrm{Cr}$ and Se or their co-supplementation on semen qualitative parameters (EV, SV, Conc., TSE, Viab, MI and TA) as well as RT are shown in Table 4. A significant interaction was found between Se and Cr for Conc., Viab, MI and TA (P $\leq 0.05)$. Concentration of spermatozoa (Conc.) was not significantly different between groups supplemented with $\mathrm{Cr}$ and Se alone (treat $2 \& 3$ ) and control (treat 1) although its mean value was slightly higher in the Se alone (treat 3). However $\mathrm{Cr}$ and Se co-supplementation (treat 4) reduced Conc compared to Se alone. Chromium supplementation alone or co-supplemented with Se increased significantly Viab and MI compared to control and morphologically abnormal spermatozoa decreased significantly by Se, Cr or their co-supplementation $(P \leq 0.05)$. Interaction between Se and $\mathrm{Cr}(\mathrm{Se} \times \mathrm{Cr})$ was not significant for EV, SV and RT. Main effect of $\mathrm{Cr}$ for RT was significant $(\mathrm{P} \leq 0.05)$ and $\mathrm{Cr}$ 
supplementation significantly resulted in lower RT (P $\leq 0.05)$. Ejaculate volume, $\mathrm{SV}$ and TSE were not affected by main effects of $\mathrm{Cr}$ and $\mathrm{Se}$ $(P \leq 0.05)$. In addition, there was no significant difference between treatments. However, main effects of $\mathrm{Cr}$ tended to increase EV $(P=0.095)$.

Results of CASA detected sperm kinematic features (TM, FPM, VCL, VSL, VAP, STR, LIN, WOB, BCF and MAD) are shown in Table 5. Some of CASA detected sperm kinematic features were affected by $\mathrm{Cr}$ and Se and a significant interaction between Se and Cr was found for VSL, VCL, VAP ALH and WOB. Mean value of VCL was slightly higher in the groups supplemented with Se and $\mathrm{Cr}$ alone (treat $2 \& 3$ ) but the difference was not significant compared to control $(P>0.05)$. Numerically lower $\mathrm{VCL}$ was observed by co-supplementation of $\mathrm{Se}$ and $\mathrm{Cr}(\mathrm{P} \leq$ $0.05)$ but the difference was not significant compared to control $(P>0.05)$. Higher VAP was observed by Se supplementation but difference was not statistically significant $(P>0.05)$. There was no significant difference between treatments for VSL, ALH and WOB. Interaction between Se and Cr was not significant for TM, FPM, STR, LIN, BCF and MAD. Level of Cr affect LIN and $1 \mathrm{mg} / \mathrm{ram} /$ day Cr increased LIN compared to zero level $(P \leq 0.05)$. However, LIN did not affected by level of Se and difference was not significant between treatments $(P>$ 0.05). Total motility, FPM, STR, BCF and MAD were not significantly affected by $\mathrm{Cr}$ and Se supplementation $(\mathrm{P}>0.05)$ but $1 \mathrm{mg} / \mathrm{ram} / \mathrm{day} \mathrm{Cr}$ tended to increase FPM.

\section{Plasma concentrations of TBRAS and FRAP}

Results of dietary supplementation of $\mathrm{Cr}$ and $\mathrm{Se}$ or their co-supplementation on TBARS and FRAP concentrations of plasma on days 30 and 60 are presented in Table 6.There was not significant effect of time on TBARS and FRAP, in addition, interaction between treatment and time (treat $\times$ time) was not significant. Although, TBARS concentration on day 30 were not significantly affected by $\mathrm{Cr}$ and $\mathrm{Se}(\mathrm{P}>0.05)$ but tended to decrease in $\mathrm{Cr}$ and Se co-supplemented group $(P=0.10)$. In addition, lower TBARS concentration was observed on day 60 and total time for $\mathrm{Cr}$ and Se supplemented groups compared to control $(P \leq 0.05)$. Interaction between $\mathrm{Se}$ and $\mathrm{Cr}$ was not significant for TBARS on days 30 and 60 and total time. FRAP concentration on day 30 were not significantly affected by $\mathrm{Cr}$ and $\mathrm{Se}(\mathrm{P}>0.05)$ but higher FRAP value was detected on day 60 and total time for $\mathrm{Cr}$ and Se supplemented groups compared to control $(P \leq 0.05)$ and a significant interaction between $\mathrm{Se}$ and $\mathrm{Cr}$ was found. However no additional effect was detected by $\mathrm{Cr}$ and Se co-supplementation.

\section{Seminal plasma biochemical composition}

There were not effects of time on seminal plasma biochemical composition (TG, TC, TP, calcium, and phosphorus) and enzymes activity (ALP, AST and ALT); in addition, interaction between treatment and time (treat $\times$ time) was not significant for these parameters. Thus, overall results are presented in Table 7 for the above mentioned parameters. There was not a significant effect of time on seminal plasma glucose concentration but, interaction between treatment and time (treat $\times$ time) was significant. In addition, effect of time on seminal plasma Alb concentration was significant but, significant interaction between treatment and time (treat $\times$ time) was not detected. Interaction between Se and $\mathrm{Cr}$ was not significant for the above mentioned biochemical parameters. There was no significant difference between treatments for TG, TC, TP, calcium, and phosphorus and activity of AST and ALT. Activity of ALP was significantly affected by main effect of Cr and $1 \mathrm{mg}$ $\mathrm{Cr} / \mathrm{ram} /$ day reduced ALP activity significantly compared to zero level $(\mathrm{P} \leq 0.05)$. In addition, $\mathrm{Cr}$ alone (treat 2$)$ or combined with Se (treat 4$)$ reduced ALP activity compared to control $(P \leq 0.05)$.

\section{Discussion}

Trivalent $\mathrm{Cr}$ is considered an essential nutrient for insulin, sugar, and lipid metabolism (Cefalu and $\mathrm{Hu}, 2004$ ). While trivalent $\mathrm{Cr}$ is considered non-toxic, hexavalent $\mathrm{Cr}$ is toxic and carcinogenic and affects reproductive system negatively (Ernst, 1990). Therefore, what is used as a dietary supplement in human and animal nutrition is trivalent type of $\mathrm{Cr}$ with organic or inorganic forms. Organic forms of trace elements have advantages over inorganic forms; some of those benefits are soluble, stable, absorbable and more metabolizable and these characteristics directly impacts the animal's health and physiology (Spears, 1996). It has been reported that dietary supplementation of $\mathrm{Cr}$ alone or in combination with some trace elements such as zinc and Se, can be act as metabolic modifiers and there was a great interest in studding the interaction between these elements in physiological processes in domestic animals (Domínguez-Vara et al., 2009). Despite increasing scientific reports on the effects of Se on semen quality, but to the best of our knowledge no study until today has reported on the effect of dietary supplementation of organic $\mathrm{Cr}$ alone or combined with organic Se on semen quality, seminal plasma biochemical composition and antioxidant status in ram. Therefore, when there were no sheep studies, we had to use the results of other animal species or human studies to match and discuss the results of our study.

The animals used in this study were adults and therefore the purpose of measuring changes in BW and DMI was not to evaluate their growth performance because their time of growth has passed. The purpose of measuring BW changes and DMI and ADG was only to evaluate the effect of Se and $\mathrm{Cr}$ intake on changes in animal BW during the experiment which was likely to affect other parameters or any effect of $\mathrm{Cr}$ and Se intake on weight loss in adult animals. Human studies has reported that $\mathrm{Cr}$ intake can result in weight loss by elevating resting energy expenditure, decreasing body fat and increasing lean body mass (Diaz, et al., 2008). Some reports suggest that Cr could suppress appetite and stimulate thermogenesis through sensitization of insulin-sensitive glucoreceptors in the brain (Wang, et al., 2007). Therefore, Cr is a 
nutritional supplement that has garnered interest for use as a weight loss aid in human (Cefalu, et al., 2004). In addition, the results of various studies on the effects of Se supplementation on metabolic hormones profile and body fat composition have shown that Se could exert beneficial effects not only in reducing peripheral and central leptin resistance (through its antioxidant activity, by increasing selenoproteins activity, and by interacting with inflammatory biomarkers), but also may act via a direct effect on adipose tissue (Cavedon, et al., 2020). It is reported that Se-yeast combined with Cr-yeast had positive effects on performance and carcass composition of finishing lambs and modified blood hormones and metabolites which could improve lamb meat quality (Domínguez-Vara, et al., 2009). However, in this study BW, TG, DMI and ADG were not affected by Se or Cr intake. Therefore, it is possible that metabolic hormones or carcass composition have been affected by $\mathrm{Cr}$ and Se intake. Although, these parameters may be affected by breeds, age, animal physiological state, duration of experimental period and $\mathrm{Cr}$ and Se content of basal diet.

Semen is developed and produced in the lumen of tubuli seminiferi in the testis; therefore, there is correlation between body weight, age, and the volume of testis as well as the SC with EV. Scrotal circumference is an essential part of the breeding soundness evaluation and sperm parameters (Perumal, 2014). Whereas, in our study SC was not affected by $\mathrm{Cr}$ or Se intake (Table 3), therefore, a significant impact of $\mathrm{Cr}$ and Se on EV was not expected. In line with the results of this experiment, no significant change in SC of Ossimi rams was observed by dietary supplementation with organic Se at 0.2 and $0.5 \mathrm{ppm}$ (Baiomy et al. 2009). It was reported that different levels of inorganic Se supplementation of Brazil's ram did not influence EV (Piagentini et al., 2017). In contrast, short-term dietary supplementation of Se-enriched yeast increased significantly goat EV during the breeding season (Shi et al., 2010). No evidence was found on the effect of Cr on EV or SC in ruminants, but it was showed that organic $\mathrm{Cr}$ or Se alone or their co-supplementation in cocks from Dokki-4 strain increased EV (Attia et al 2015). According to the results obtained from this study, co-supplementation of $\mathrm{Cr}$ and Se increased slightly EV but it was not statistically significant (Table 4). Since there was no change in BW, it was not expected to observe significant increase in EV. However, we believe that EV is more influenced by, animal species, BW and breeds.

In our study sperm concentration decreased by $\mathrm{Cr}$ adding to Se contained diet, in other words, sperm concentration decreased by cosupplementation of $\mathrm{Cr}$ and $\mathrm{Se}\left(2.72\right.$ vs. $3.07 \times 10^{9} \mathrm{ml}$, Table 7) but this reduction did not happen with $\mathrm{Cr}$ or Se alone and difference was not significant with control. It may be due to slightly the greater effect of Se on sperm concentration. Therefore, it can be concluded that the combined $\mathrm{Cr}$ and Se had no negative effect on sperm concentration; in particular, the total TSE did not differ between groups. Conflicting results on reproductive effects of $\mathrm{Cr}$ compounds have been reported. No negative effects of organic $\mathrm{Cr}$ (chromium picolinate or chromium nicotinate) have been observed on male reproductive tract in previous reports (World Health Organization, 2020). Chromium picolinate in the diet of male rats for 3 months did not produce adverse effects on reproductive tissues, as assessed by organ weights, gross and histopathological examinations, sperm count and sperm motility (Rhodes, et al., 2005). All the negative effects reported in the previous documents are related to the inorganic forms (Cr-sulfate or Cr-chloride in drinking water). For example, decreased spermatogenesis was observed in Balb/c mice treated with $9.1 \mathrm{mg}$ as Cr-sulfate $/ \mathrm{kg} /$ day in drinking water for 7 weeks. In addition, significantly lower absolute weight of testes, seminal vesicles, and preputial glands was observed in male Sprague-Dawley rats with intake of $40 \mathrm{mg} \mathrm{Cr-sulfate} / \mathrm{kg} / \mathrm{day}$. It is unclear if differences in results are related to experimental methods, including exposure media (drinking water versus feed), or to differences in toxicity of the specific trivalent chromium compounds evaluated (World Health Organization, 2020). Considering that in our study we used the organic form of $\mathrm{Cr}$ (CrMet) with very lower dose compared to previous studies, it is unlikely can link the reduced sperm count to toxicity effect of CrMet however, it may need more detailed toxicological study in ram.

The positive effects of $\mathrm{Cr}$ or Se alone or their combination on semen quality were appeared in higher sperm viability, membrane integrity and lower abnormal spermatozoa (Table 4). Similar to results of $\mathrm{Cr}$ treated group, Horký et al. (2011) reported that $\mathrm{Cr}$ supplementation of boars diet ( $181.81 \mu \mathrm{g}$ per $\mathrm{kg}$ of diet), after 95 days, sperm concentration and motility were absolutely the same in boars of control group and the beneficial effect of $\mathrm{Cr}$ was seen in the reduced count of pathological sperm in boars. In Se treated group, results of sperm survival and abnormality were in agreement and sperm motility and concentration were disagreement with previous human and animal studies (Kendall et al., 2000, Hawkes and Turek, 2001 and Shi et al., 2010). It is reported that hot weather, such as long periods of temperatures over $32^{\circ} \mathrm{C}$, or short spells of very high temperatures $\left(38^{\circ} \mathrm{C}\right.$ or higher), affects the production of viable sperm in ram. As the climatologically data of this experiment shows (Table 2), animals of this study were more likely to experience temperatures above $32{ }^{\circ} \mathrm{C}$ in the summer. Therefore, the presence of heat stress in animals of this study is likely. It is reported that heat stress alters post-absorptive carbohydrate (basal and stimulated) metabolism, characterized primarily by increased basal insulin concentrations and insulin response to a glucose tolerance test (O'brien et al., 2010). The positive effects observed in this study for sperm cells viability, membrane integrity and reduced abnormality may be linked to antioxidant properties of $\mathrm{Cr}$ and Se. It is reported that, dietary antioxidant supplementation of stallions (Deichsel et al., 2008), rats (Wu et al., 1979) and goats (Shi et al., 2010) could lead to a significant reduction of morphologically abnormal spermatozoa. There are growing evidences show that $\mathrm{Se}$ or $\mathrm{Cr}$ supplementation could improve antioxidant status and can be used as effective treatment strategy for minimize adverse effects of free radicals in rats (Sundaram et al., 2013), diabetic patients (Cheng et al., 2004) and infertile men (Alahmar et al., 2021). Scientific documents emphasize that Se and $\mathrm{Cr}$ are a promising agent for combating the adverse effects of stress in animals and 
is a strong antioxidant that prevents heat stress-induced lipid per-oxidation, improves nutrient metabolism and cortisol hormone activity, promotes insulin action in responsive tissues, thereby increasing farm animal productivity (Bin-Jumah, et al., 2020). Recent findings suggest that dietary high chromium-methionine supplementation in summer-exposed animals improves blood antioxidant status and feed to gain efficiency without adverse effects on lambs' health and metabolism (Seifalinasab et al., 2021). Accompanying these studies, Biswas et al. (2014) reported that 500 or $750 \mu \mathrm{g} / \mathrm{kg}$ Cr-picolinate in diet of adult male turkeys in summer improve sperm concentration, progressive motility and fertility. In our study the higher FRAP and lower TBARS concentrations with $\mathrm{Cr}$ and Se or their co-supplementation (Table 6) indicate the positive effects of $\mathrm{Cr}$ and Se on blood antioxidant status in rams, which in turn may be responsible for these positive effects on viability, membrane integrity and reduced abnormally. Oxidative stress is common cause of low sperm quality. In high levels, reactive oxygen species (ROS) can affect sperm motility, increase sperm abnormality as well as impair sperm capacitation, acrosome reaction, and the fertilizing ability (Agarwal et al., 1994). In contrast to our results, it was reported that supplementation of chromium picolinate (3.5 mg of $\mathrm{Cr} /$ cow daily) under hot conditions did not have an effect on antioxidant activities such as serum total antioxidant capacity, superoxide dismutase (SOD) activity, or MDA levels of lactating cows (Qi et al., 2018). In calves receiving Cr-methionine at levels of 0.05 mg Cr/ $\mathrm{kg}$ of body weight at weaning, Cr pplementations do not influence malondialdehyde (MDA) or glutathione peroxidase (GPx) serum levels, but the concentration of superoxide dismutase (SOD) tended to increase (Jin et al., 2017). In line with our study, it was found that Cr supplementation reduced serum concentration of MDA, in stressed hens (Sahin et al,m 2002). In addition, Anderson et al. (2001) reported that 6 months of $\mathrm{Cr}$ supplementation ( $400 \mu \mathrm{g}$ of chromium pidolate) in people with type 2 Diabetic patient could significantly reduce plasma TBARS and not significantly change antioxidant enzymes such as SOD and GPX. The mechanism by which Cr acted as an antioxidant is still not totally understood. Contradictory results in different studies are significantly related to the amount of $\mathrm{Cr}$ used, duration of $\mathrm{Cr}$ intake, severity of stress, $\mathrm{Cr}$ concentration in basal diet, forms of $\mathrm{Cr}$ and physiologic condition could affect results.

In our study daily $\mathrm{Cr}$ intake (1 mg/ram/ day for 60 days) increases sperm linearity (VSL/VCL) as a measure of a curvilinear path, in addition VSL and VAP had numerically higher mean value but intake of combined $\mathrm{Cr}$ and Se reduced VCL compared to Se or Cr alone. This reduction did not happen with each of $\mathrm{Cr}$ or Se alone and difference was not significant with control. It may be due to slightly the greater effect of $\mathrm{Cr}$ and Se alone on VCL. Therefore, it can be concluded that the combined Cr and Se had no negative effect on VCL. Total motility and FPM did not changed significantly but FPM tended to increase by Cr intake. In agreement with our results, Shanmugam et al (2020) reported that organic $\mathrm{Cr}$ supplementation did not improve sperm total motility, fertility and hatchability in layer breeders. Beyond, $2.5 \% \mathrm{Cr}$-yeast supplementation of rabbit diet improved sperm progressive motility (Shabaan et al., 2014). It was reported that during stress conditions the requirement of $\mathrm{Cr}$ increases and supplementation of Cr may have some positive effects (spears, 2019). In the present study ram experienced summer heat stress but stress intensity may not to be so severe to affect parameters significantly.

Rams in Cr or combined $\mathrm{Cr}$ and Se supplemented groups were expressed more sexual behaviors and readily court and ejaculate when expose to stimulus as showed with lower reaction time (Table 4). It is reported that, most adult rams readily court, mount, and ejaculate when exposed for a brief periods to females in estrus. Minimal threshold concentrations of testosterone are required for reaction of ram to stimulus (D'Occhio and Brooks, 1982). Testosterone and its androgenic components and estrogenic signaling pathways in the nervous system are critical for the expression of sexual behaviors (Sachs and Meisel, 1994). It is reported that testosterone levels were significantly increased with Cr supplementation in streptozotocin treated rats (Abu-zaiton et al 2021). In addition study with goats showed that Se supplementation, after 60 days, increased serum testosterone concentration (Kumar et al. 2013). Testosterone measurement conditions were not met in our experiment but, the lower reaction time with $\mathrm{Cr}$ was significant $(\mathrm{P} \leq 0.05)$. The insignificant difference in the $\mathrm{Cr}$ group with control may be related to the animal's health and the adequacy of the basic dietary Cr concentration for maintains normal testosterone biosynthesis and libido. In general, the more positive effects of $\mathrm{Cr}$ supplementation on libido are likely to be seen in patient or animals with impaired glucose metabolism (Abu-zaiton et al 2021).

In this study, seminal plasma ALP reduced significantly by Cr or combined Cr and Se intake but no effect on the level of ALT and AST was detected. In addition, activities of these enzymes did not affected by Se alone. In contrast to results of our study, Cr as Cr-picolinate, at 500 and $750 \mu \mathrm{g} / \mathrm{kg}$ levels in diet of male turkeys, did not affect seminal plasma ALP (Biswas et al., 2014). Alkaline phosphatase, ALT and AST are enzymes that are associated with the activities of cell division, metabolism and energy transfer. The measures of the alteration of these enzymes are markers that indicate the degree of damage to the testicular tissue (Long et al., 2017). The decline in ALP activity in Cr or their combination groups may relate to protective action of $\mathrm{Cr}$ and Se on parenchyma of testis or sperm cell membrane which leads to a decline in the release of ALP in seminal plasma (Ebrahimzadeh et al., 2013). The rate of generation of free radicals in testis or spermatozoa appears to be temperature-dependent. Spontaneous lipid peroxidation and generation of TBARS, has been reported to increase with temperature elevation (Alvarez and Storey, 1985). Antioxidant treatment, which enhances the endogenous antioxidant defense, can inhibit germ cells apoptosis and semen quality and decrease enzyme release in to seminal plasma (Verhaegen et al., 1995). It was reported that rabbit seminal plasma ALP activity is negatively correlated with sperm concentration but there was no significant correlation with CASA detected parameters (Viudes-De-Castro et al., 2015). 
Selenium or Cr supplementation in our study had no significant effect on seminal plasma TG, TC, TP Alb, calcium and phosphorus concentrations but glucose concentration reduced by $\mathrm{Cr}$ intake. In line to results of our study, $\mathrm{Cr}$ as $\mathrm{Cr}$-picolinate, at 500 and $750 \mu \mathrm{g} / \mathrm{kg}$ levels in diet of male turkeys reduced glucose concentration, in contrast increase TP and TC concentrations (Biswas et al., 2014). Glucose in seminal plasma is important for ATP production, sperm capacitation and acrosome reaction and low content of seminal proteins is associated with poor semen quality (Baas et al., 1983). Chromium is glucose tolerance factor (GTF) and potentiates insulin action and increases the uptake of glucose by cells (Weksler-Zangen et al., 2012). Therefore lower seminal plasma glucose concentration in Cr treated rams in the current study may support this suggestion.

\section{Conclusion}

The results of the present study allow to conclude that the positive effects of organic chromium supplementation alone or combined with organic selenium was appeared in improved sperm, viability, membrane integrity, some motility parameters, libido, blood antioxidant status and morphologically abnormal spermatozoa. Therefore, it can be suggested to the sheep breeders to supplement the ram's diet with organic selenium or chromium two months before mating, but using combination of selenium and chromium in severe stress situations requires more research.

\section{Declarations}

Acknowledgment This study has been adapted from an MSc thesis at Bu-Ali Sina University, Hamadan, Iran. We thank staffs and postgraduate students from department of animal science at University of Bu-Ali Sina for collecting samples and technicians from Paraveterinary laboratory of Bu-Ali Sina University for providing technical assistance in computer-assisted sperm analysis (CASA) and seminal plasma biochemical assessment.

Author contribution All authors contributed to the study conception and design. Material preparation, data collection and analysis were performed by Abbas Farahavar, Amirhosein Mehranforooz, Morteza Yavari and Ahmad Ahmadi. The first draft of the manuscript was written by Abbas Farahavar and all authors commented on previous versions of the manuscript. All authors read and approved the final manuscript.

Funding The present study was funded by Vice-chancellor for Research and Technology, Hamadan University of Bu-Ali Sina, (grant No. 1021076).

Data availability All data generated or analyzed during this study are included in this published paper.

Ethics approval The experimental design and procedures in the present study were reviewed and approved by the research policy of the ethical committee of the Bu-Ali Sina University and the experiment was performed under veterinary care.

Consent to participate Not applicable.

Consent for publication Not applicable.

Conflict of interest The authors declare no competing interests.

\section{References}

1. Abu-zaiton, A., Almuhur, R., Algaramseh, A., and Alwardat, D. 2021. The impact of chromium supplementation on carbohydrates, liver function, kidney function and testosterone levels in diabetic rats. Materials Today: Proceedings. https://doi.org/10.1016/j.matpr.2021.05.599

2. Agarwal, A., Ikemoto, I., \& Loughlin, K. R. 1994. Relationship of sperm parameters with levels of reactive oxygen species in semen specimens. The Journal of urology, 152(1), 107-110. https://doi.org/10.1016/S0022-5347(17)32829-X

3. Alahmar, A.T., and Sengupta, P. 2021. Impact of coenzyme Q10 and selenium on seminal fluid parameters and antioxidant status in men with idiopathic infertility. Biological trace element research, 199(4), 1246-1252. https://doi.org/10.1007/s12011-020-02251-3

4. Alvarez, J.G., \& Storey, B.T. 1985. Spontaneous lipid peroxidation in rabbit and mouse epididymal spermatozoa: dependence of rate on temperature and oxygen concentration. Biology of reproduction, 32(2), 342-351. https://doi.org/10.1095/biolreprod32.2.342

5. Anderson, R.A., Roussel, A.M., Zouari, N., Mahjoub, S., Matheau, J.M., \& Kerkeni, A. 2001. Potential antioxidant effects of zinc and chromium supplementation in people with type 2 diabetes mellitus. Journal of the American College of Nutrition, 20(3), 212-218. https://doi.org/10.1080/07315724.2001.10719034 
6. Anzar, M., Kroetsch, T., \& Buhr, M.M. 2009. Comparison of different methods for assessment of sperm concentration and membrane integrity with bull semen. Journal of andrology, 30(6), 661-668. https://doi.org/10.2164/jandrol.108.007500

7. AOAC, 1997. Official Methods of Analysis, 16th ed. Association of Official Analytical Chemists, Arlington, VA, USA.

8. Attia, K.M., Tawfik, F.A., Mady, M.S., and Assar, M.H. 2015. Effect of dietary chromium, selenium and vitamin c supplementation to the diet on reproductive performance and egg quality of laying hen dokki-4 under Egyptian summer condition. Egyptian Journal of Nutrition and Feeds, 18(2 Special), 345-359. 10.21608/ejnf.2015.104493

9. Baas, J.W., Molan, P.C., \& Shannon, P. 1983. Factors in seminal plasma of bulls that affect the viability and motility of spermatozoa. Reproduction, 68(2), 275-280. https://doi.org/10.1530/jrf.0.0680275

10. Baiomy, A.A., Mohamed, A. E.A., \& Mottelib, A.A. 2009. Effect of dietary selenium and vitamin E supplementation on productive and reproductive performance in rams. Journal of Veterinary Medical Research, 19(1), 39-43. 10.21608/jvmr.2009.77807

11. Bin-Jumah, M., Abd El-Hack, M.E., Abdelnour, S.A., Hendy, Y.A., Ghanem, H.A., Alsafy, S.A., \& Aleya, L. 2020. Potential use of chromium to combat thermal stress in animals: A review. Science of the Total Environment, 707, 135996.

https://doi.org/10.1016/j.scitotenv.2019.135996

12. Biswas, A., Divya, S., Mandal, A.B., Majumdar, S., and Singh, R. 2014. Effects of dietary supplementation of organic chromium (picolinate) on physical and biochemical characteristics of semen and carcass traits of male turkeys. Animal reproduction science, 151(3-4), 237-243. https://doi.org/10.1016/j.anireprosci.2014.10.007

13. Cavedon, E., Manso, J., Negro, I., Censi, S., Serra, R., Busetto, L., \& Mian, C. 2020. Selenium supplementation, body mass composition, and leptin levels in patients with obesity on a balanced mildly hypocaloric diet: a pilot study. International journal of endocrinology, 2020(1) 1-7. https://doi.org/10.1155/2020/4802739

14. Cefalu, W.T., and Hu, F.B. 2004. Role of chromium in human health and in diabetes. Diabetes care, 27(11), $2741-2751$. https://doi.org/10.2337/diacare.27.11.2741

15. Chauhan, S.S., Celi, P., Leury, B.J., Clarke, I.J., and Dunshea, F.R. 2014. Dietary antioxidants at supra-nutritional doses improve oxidative status and reduce the negative effects of heat stress in sheep. Journal of Animal Science, 92(8), 3364-3374. https://doi.org/10.2527/jas.2014-7714

16. Cheng, H.H., Lai, M.H., Hou, W.C., and Huang, C.L. 2004. Antioxidant effects of chromium supplementation with type 2 diabetes mellitus and euglycemic subjects. Journal of agricultural and food chemistry, 52(5), 1385-1389. https://doi.org/10.1021/jf035074j

17. Diaz, M.L., Watkins, B.A., Li, Y., Anderson, R.A., \& Campbell, W.W. 2008. Chromium picolinate and conjugated linoleic acid do not synergistically influence diet-and exercise-induced changes in body composition and health indexes in overweight women. The Journal of nutritional biochemistry, 19(1), 61-68. https://doi.org/10.1016/j.jnutbio.2007.01.006

18. D'Occhio, M.J., and Brooks, D.E. 1982. Threshold of plasma testosterone required for normal mating activity in male sheep. Hormones and behavior, 16(4), 383-394. https://doi.org/10.1016/0018-506X(82)90047-2

19. Domínguez-Vara, I.A., González-Muñoz, S.S., Pinos-Rodríguez, J.M., Bórquez-Gastelum, J.L., Bárcena-Gama, R., Mendoza-Martínez, G., Zapata, L.E., and Landois-Palencia, L. L. 2009. Effects of feeding selenium-yeast and chromium-yeast to finishing lambs on growth, carcass characteristics, and blood hormones and metabolites. Animal Feed Science and Technology, 152(1-2), 42-49. https://doi.org/10.1016/j.anifeedsci.2009.03.008

20. Ebrahimzadeh, S., Farhoomand, P., \& Noori, K. 2013. Effects of chromium methionine supplementation on performance, carcass traits, and the $\mathrm{Ca}$ and $\mathrm{P}$ metabolism of broiler chickens under heat-stress conditions. Journal of Applied Poultry Research, $22(3), 382-387$. https://doi.org/10.3382/japr.2011-00506

21. Ernst, E. 1990. Testicular toxicity following short-term exposure to tri-and hexavalent chromium: an experimental study in the rat. Toxicology letters, 51(3), 269-275. https://doi.org/10.1016/0378-4274(90)90069-X

22. Fahey, A.G., Duffy, P., and Fair, S. 2012. Effect of exposing rams to a female stimulus before semen collection on ram libido and semen quality. Journal of animal science, 90(10), 3451-3456. https://doi.org/10.2527/jas.2011-4859

23. Farahavar, A., Rostami, Z., Alipour, D., \& Ahmadi, A. 2020. The effect of pre-breeding vitamin E and selenium injection on reproductive performance, antioxidant status, and progesterone concentration in estrus-synchronized Mehraban ewes. Tropical animal health and production, 52(4), 1779-1786. https://doi.org/10.1007/s11250-019-02183-8

24. Ghorbankhani, F., Souri, M., Moeini, M.M., and Mirmahmoudi, R. 2015. Effect of nutritional state on semen characteristics, testicular size and serum testosterone concentration in Sanjabi ram lambs during the natural breeding season. Animal reproduction science, 153, 2228. https://doi.org/10.1016/j.anireprosci.2014.12.006

25. Hawkes, W.C., and Turek, P. J. 2001. Effects of dietary selenium on sperm motility in healthy men. Journal of Andrology, $22(5), 764-772$. https://doi.org/10.1002/j.1939-4640.2001.tb02579.x

Page 9/17 
26. Horky, P., Jancikova, P., and Zeman, L. 2012. The effect of a supplement of chromium (picolinate) on the level of blood glucose, insulin activity and changes in laboratory evaluation of the ejaculate of breeding boars. Acta Universitatis Agriculturae et Silviculturae Mendelianae Brunensis, 60(1), 49-56. 10.11118/ACTAUN201260010049

27. Hosny, N.S., Hashem, N.M., Morsy, A.S., and Abo-Elezz, Z. R. 2020. Effects of organic selenium on the physiological response, blood metabolites, redox status, semen quality, and fertility of rabbit bucks kept under natural heat stress conditions. Frontiers in Veterinary Science, 7, 290.

28. Jin, D., Kang, K., Wang, H., Wang, Z., Xue, B., Wang, L., \& Peng, Q. 2017. Effects of dietary supplementation of active dried yeast on fecal methanogenic archaea diversity in dairy cows. Anaerobe, 44, 78-86. https://doi.org/10.1016/j.anaerobe.2017.02.007

29. Kendall, N.R., McMullen, S., Green, A., and Rodway, R. G. 2000. The effect of a zinc, cobalt and selenium soluble glass bolus on trace element status and semen quality of ram lambs. Animal Reproduction Science, 62(4), 277-283. https://doi.org/10.1016/S03784320(00)00120-2

30. Kumar, P., Yadav, B., and Yadav, S. 2013. Effect of zinc and selenium supplementation on antioxidative status of seminal plasma and testosterone, T4 and T3 level in goat blood serum. Journal of applied animal research, 41(4), 382-386. https://doi.org/10.1080/09712119.2013.783482

31. Long, M., Yang, S., Dong, S., Chen, X., Zhang, Y., \& He, J. 2017. Characterization of semen quality, testicular marker enzyme activities and gene expression changes in the blood testis barrier of Kunming mice following acute exposure to zearalenone. Environmental Science and Pollution Research, 24(35), 27235-27243. https://doi.org/10.1007/s11356-017-0299-1

32. Marai, I.F.M., El-Darawany, A.H., Ismail, E., \& Abdel-Hafez, M.A.M. 2009. Reproductive and physiological traits of Egyptian Suffolk rams as affected by selenium dietary supplementation and housing heat radiation effects during winter of the sub-tropical environment of Egypt. Archives Animal Breeding, 52(4), 402-409. https://doi.org/10.5194/aab-52-402-2009

33. Molinia, F.C., Evans, G., \& Maxwell, W.M.C. 1994. Incorporation of penetrating cryoprotectants in diluents for pellet-freezing rams spermatozoa. Theriogenology, 42(5), 849-858. https://doi.org/10.1016/0093-691X(94)90453-P

34. NRC 2007. Committee on the Nutrient Requirements of Small Ruminants, Board on Agriculture, Division on Earth, and Life Studies. Nutrient requirements of small ruminants: sheep, goats, cervids, and new world camelids. Washington, D.C., USA.

35. O'brien, M.D., Rhoads, R.P., Sanders, S.R., Duff, G.C., and Baumgard, L. H. 2010. Metabolic adaptations to heat stress in growing cattle. Domestic animal endocrinology, 38(2), 86-94. https://doi.org/10.1016/j.domaniend.2009.08.005

36. Perumal, P. 2014. Scrotal circumference and its relationship with testicular growth, age, and body weight in Tho Tho (Bos indicus) bulls. International scholarly research notices. https://doi.org/10.1155/2014/249537

37. Piagentini, M., Silva, D.C., Dell'Aqua, C.P.F., Moya-Araujo, C.F., Codognoto, V.M., Ramos, A.A., and Oba, E. 2017. Effect of selenium supplementation on semen characteristics of Brazil's ram. Reproduction in Domestic Animals, 52(3), 355-358. https://doi.org/10.1111/rda.12903

38. Qi, Z., Gao, J., Zhao, C., Zhang, Y., Liu, Y., Wang, X., \& Li, H. 2018. PSXVII-30 Effects of dietary supplementation of yeast chromium and dihydropyridine on serum biochemical indices and HSP70 mRNA expression of lactating dairy cows in summer. Journal of Animal Science, 96(suppl_3), 448-449. https://doi.org/10.1093/jas/sky404.979

39. Rhodes, M.C., Hébert, C.D., Herbert, R.A., Morinello, E.J., Roycroft, J.H., Travlos, G.S., \& Abdo, K.M. 2005. Absence of toxic effects in F344/N rats and B6C3F1 mice following subchronic administration of chromium picolinate monohydrate. Food and chemical toxicology, 43(1), 21-29. https://doi.org/10.1016/j.fct.2004.08.006

40. Sachs, B.D., and Meisel, R.L. 1994. The physiology of male sexual behavior. In: Knobil E, Neil J (eds.), The Physiology of Reproduction, 2nd ed. New York: Raven Press; 3-105.

41. Sahin, K., Sahin, N., \& Kucuk, O. 2002. Effects of dietary chromium and ascorbic acid supplementation on digestion of nutrients, serum antioxidant status, and mineral concentrations in laying hens reared at a low ambient temperature. Biological trace element research, 87(1), 113-124. https://doi.org/10.1385/BTER:87:1-3:113

42. Seifalinasab, A., Mousaie, A., and Doomary, H. 2021. Dietary High Chromium-Methionine Supplementation in Summer-Exposed Finishing Lambs: Impacts on Feed Intake, Growth Performance, and Blood Cells, Antioxidants, and Minerals. Biological Trace Element Research, 1-8. https://doi.org/10.1007/s12011-021-02633-1

43. Shabaan, H., Gaballah, S., Abdel-Kafy, E. S., \& Ghazal, M. 2014. Productive and physiological responses of New Zealand White rabbit males to dietary organic chromium addition. Egyptian Journal of Rabbit Science, 24(1), 1-18. 10.21608/ejrs.2014.47466

44. Shanmugam, M., Prakash, B., \& Panda, A. K. 2020. Effect of dietary organic zinc and chromium supplementation on semen quality in layer breeder. Indian Journal of Poultry Science, 55, 132-138 0.5958/0974-8180.2020.00021.5 
45. Shi, L., Zhang, C., Yue, W., Shi, L., Zhu, X., and Lei, F. 2010. Short-term effect of dietary selenium-enriched yeast on semen parameters, antioxidant status and Se concentration in goat seminal plasma. Animal feed science and technology, 157(1-2), 104-108. https://doi.org/10.1016/j.anifeedsci.2010.02.006

46. Spears, J.W. 1996. Organic trace minerals in ruminant nutrition. Animal feed science and technology, 58(1-2), 151-163. https://doi.org/10.1016/0377-8401(95)00881-0

47. Spears, J.W. 2019. Boron, chromium, manganese, and nickel in agricultural animal production. Biological trace element research, 188(1), 35-44. https://doi.org/10.1007/s12011-018-1529-1

48. Sundaram, B., Aggarwal, A., and Sandhir, R. 2013. Chromium picolinate attenuates hyperglycemia-induced oxidative stress in streptozotocin-induced diabetic rats. Journal of Trace Elements in Medicine and Biology, 27(2), 117-121.

https://doi.org/10.1016/j.jtemb.2012.09.002

49. Van Soest, P. V., Robertson, J. B., and Lewis, B. 1991. Methods for dietary fiber, neutral detergent fiber, and nonstarch polysaccharides in relation to animal nutrition. Journal of dairy science, 74(10), 3583-3597. https://doi.org/10.3168/jds.S0022-0302(91)78551-2

50. Van Wettere, W.H., Kind, K.L., Gatford, K.L., Swinbourne, A.M., Leu, S.T., Hayman, P.T., Kelly, J.M., Weaver, A.C., Kleemann, D.O and Walker, S. K. 2021. Review of the impact of heat stress on reproductive performance of sheep. Journal of Animal Science and Biotechnology, 12(1), 1-18. https://doi.org/10.1186/s40104-020-00537-z

51. Verhaegen, S., McGowan, A.J., Brophy, A.R., Fernandes, R.S., \& Cotter, T.G. 1995. Inhibition of apoptosis by antioxidants in the human HL60 leukemia cell line. Biochemical pharmacology, 50(7), 1021-1029. https://doi.org/10.1016/0006-2952(95)00233-P

52. Viudes-De-Castro, M.P., Casares-Crespo, L., Monserrat-Martínez, A., \& Vicente, J.S. 2015. Determination of enzyme activity in rabbit seminal plasma and its relationship with quality semen parameters. World Rabbit Science, 23(4), 247-253. 10.4995/wrs.2015.4064

53. Wang, Z.Q., Qin, J., Martin, J., Zhang, X.H., Sereda, O., Anderson, R.A., \& Cefalu, W.T. 2007. Phenotype of subjects with type 2 diabetes mellitus may determine clinical response to chromium supplementation. Metabolism, 56(12), 1652-1655. https://doi.org/10.1016/j.metabol.2007.07.007

54. Weksler-Zangen, S., Mizrahi, T., Raz, I., \& Mirsky, N. 2012. Glucose tolerance factor extracted from yeast: oral insulin-mimetic and insulinpotentiating agent: in vivo and in vitro studies. British Journal of Nutrition, 108(5), 875-882. https://doi.org/10.1017/S0007114511006167

55. WHO. 2020. Chromium in Drinking-water (No. WHO/HEP/ECH/WSH/2020.3). World Health Organization.

\section{Tables}


Table 1

Chemical composition of feed ingredient and basal diet*

\begin{tabular}{|c|c|c|c|c|c|c|}
\hline $\begin{array}{l}\text { Feed Ingredients } \\
\text { (as \% of Dry Matter) }\end{array}$ & $\begin{array}{l}\text { Alfalfa } \\
\text { hay }\end{array}$ & $\begin{array}{l}\text { Barely } \\
\text { Straw }\end{array}$ & $\begin{array}{l}\text { Barely } \\
\text { grain }\end{array}$ & $\begin{array}{l}\text { Soybean } \\
\text { meal }\end{array}$ & $\begin{array}{l}\text { Wheat } \\
\text { bran }\end{array}$ & $\begin{array}{l}\text { Basal } \\
\text { diet }\end{array}$ \\
\hline Dry Matter (\%) & 93.1 & 95.23 & 91.00 & 91.00 & 89.1 & 93.20 \\
\hline Crude Protein (\%) & 14.5 & 4.41 & 11.3 & 44.00 & 16.5 & 13.30 \\
\hline $\mathrm{ME}(\mathrm{Mcal} / \mathrm{Kg})^{2}$ & 2.1 & 1.5 & 3.00 & 3.1 & 2.50 & 2.18 \\
\hline NDF (\%) & 43.86 & 7.75 & 20.86 & 9.00 & 46.00 & 32.20 \\
\hline ADF (\%) & 32.56 & 53.00 & 7.00 & 6.00 & 13.00 & 20.31 \\
\hline Calcium (\%) & 1.8 & 0.06 & 0.063 & 0.28 & 0.05 & 2.03 \\
\hline Phosphorus (\%) & 0.19 & 0.07 & 0.38 & 0.70 & 0.24 & 0.24 \\
\hline Iron (ppm) & 492.48 & 78.26 & 471.92 & 74.42 & 471.89 & 324.3 \\
\hline Zinc (ppm) & 20.13 & 7.15 & 18.82 & 16.74 & 18.70 & 2.65 \\
\hline Copper (ppm) & 15.55 & 5.20 & 2.8 & 2.87 & 2.90 & 7.09 \\
\hline \multicolumn{6}{|l|}{ Selenium (ppm) } & 0.06 \\
\hline \multicolumn{6}{|l|}{ Chromium (ppm) } & 1.61 \\
\hline \multicolumn{7}{|c|}{$\begin{array}{l}\text { *Basal diet contains: Alfalfa hay }(42 \%) \text {, Barely straw ( } 28 \%) \text {, Barely grain }(19.20 \%) \text {, Soybean meal }(3 \%), \text { Wheat Bran }(7.5 \%), \mathrm{NaCl}(0.3 \%) \text {; } \\
\text { ME: Metabolizable energy as Mcal/Kg was estimated by using NRC (2007). NDF: Neutral detergent fiber (\% of Dry Matter), ADF: Acid } \\
\text { detergent fiber (\% of Dry Matter). }\end{array}$} \\
\hline
\end{tabular}

Table 2

Climatological parameters for the experimental period

\begin{tabular}{|llllllll|}
\hline & \multicolumn{2}{l}{ Ambient temperature $\left(^{\circ} \mathrm{C}\right)$} & \multicolumn{2}{c|}{ Relative humidity (\%) } \\
\hline & Mean & Min & Max & mean & min & max & Month mean \\
\hline 22 June - 22 July & 24.87 & 16.58 & 33.16 & 24.48 & 10.19 & 38.77 & $14: 21$ \\
\hline 23 July - 22 August & 27.35 & 21.48 & 33.22 & 17.16 & 9.32 & 25 & $13: 48$ \\
\hline 23 August - 22 September & 24.74 & 18.67 & 30.80 & 15.98 & 8.58 & 23.38 & $12: 50$ \\
\hline
\end{tabular}


Table 3

Effect of organic selenium alone or combined with organic chromium on body weight changes and scrotal circumference of Mehraban rams1.

\begin{tabular}{|c|c|c|c|c|c|c|c|c|}
\hline Treatments & $\begin{array}{l}\mathrm{Cr} \\
\mathrm{mg} / \mathrm{d}\end{array}$ & $\begin{array}{l}\mathrm{Se} \\
\mathrm{mg} / \mathrm{d}\end{array}$ & $\begin{array}{l}\text { Initial WB, } \\
\text { kg }\end{array}$ & $\begin{array}{l}\text { Final BW, } \\
\text { kg }\end{array}$ & $\begin{array}{l}\text { TG } \\
\text { kg }\end{array}$ & $\begin{array}{l}\text { DMI } \\
\mathrm{kg}\end{array}$ & $\begin{array}{l}\text { ADG, } \\
\text { g/d }\end{array}$ & $\begin{array}{l}\mathrm{SC}, \\
\mathrm{cm}\end{array}$ \\
\hline 1 (control) & 0 & 0 & 68.67 & 72.75 & 4.07 & 1.60 & 72.77 & 32.33 \\
\hline 2 & 1 & 0 & 68.90 & 74.37 & 5.48 & 1.55 & 97.99 & 33.75 \\
\hline 3 & 0 & 0.6 & 70.10 & 71.25 & 6.12 & 1.57 & 109.38 & 33.00 \\
\hline 4 & 1 & 0.6 & 72.38 & 77.32 & 4.94 & 1.59 & 88.21 & 31.80 \\
\hline SEM & & & 4.97 & 3.66 & 1.10 & 0.03 & 19.77 & 1.56 \\
\hline \multicolumn{9}{|c|}{ Cr Main effect } \\
\hline 0 & & & 69.46 & 72.00 & 5.10 & 1.58 & 91.07 & 32.66 \\
\hline 1 & & & 70.82 & 76.01 & 5.18 & 1.56 & 92.56 & 32.78 \\
\hline SEM & & & 3.50 & 2.58 & 0.78 & 0.02 & 13.94 & 1.04 \\
\hline \multicolumn{9}{|c|}{ Se main effect } \\
\hline 0 & & & 68.78 & 73.56 & 4.78 & 1.57 & 85.38 & 33.04 \\
\hline 0.6 & & & 71.24 & 74.62 & 5.46 & 1.58 & 97.62 & 32.40 \\
\hline SEM & & & 3.50 & 2.58 & 0.78 & 0.02 & 13.94 & 1.04 \\
\hline \multicolumn{9}{|c|}{ Statistical significance } \\
\hline Cr effect & & & NS & NS & NS & NS & NS & NS \\
\hline Se effect & & & NS & NS & NS & NS & NS & NS \\
\hline $\mathrm{Cr} \times \mathrm{Se}$ inter & & & NS & NS & NS & NS & NS & NS \\
\hline
\end{tabular}


Table 4

Effect of organic selenium alone or combined with organic chromium on semenquantitative parameters and libido in Mehrban rams1

\begin{tabular}{|c|c|c|c|c|c|c|c|c|c|c|}
\hline Treats & $\begin{array}{l}\mathrm{Cr} \\
\mathrm{mg} / \mathrm{d}\end{array}$ & $\begin{array}{l}\mathrm{Se} \\
\mathrm{mg} / \mathrm{d}\end{array}$ & $\begin{array}{l}\mathrm{EV}, \\
\mathrm{ml}\end{array}$ & $\begin{array}{l}\text { MM, } \\
(0-5)\end{array}$ & $\begin{array}{l}\text { Conc, } \\
\times 10^{9} \cdot \mathrm{ml}^{-1}\end{array}$ & $\begin{array}{l}\text { TSE, } \\
\times 10^{9}\end{array}$ & $\begin{array}{l}\text { Viab, } \\
\%\end{array}$ & $\begin{array}{l}\text { MI, } \\
\%\end{array}$ & $\begin{array}{l}\mathrm{TA}, \\
\%\end{array}$ & $\begin{array}{l}\text { RT, } \\
s\end{array}$ \\
\hline 1 (Control) & 0 & 0 & 1.26 & 4.33 & $2.80^{\mathrm{ab}}$ & 3.48 & $89.76^{b}$ & $81.42^{b}$ & $6.12^{\mathrm{a}}$ & 15.08 \\
\hline 2 & 1 & 0 & 1.27 & 4.54 & $2.81^{\mathrm{ab}}$ & 3.53 & $91.92^{\mathrm{a}}$ & $87.00^{\mathrm{a}}$ & $4.52^{b}$ & 14.41 \\
\hline 3 & 0 & 0.6 & 1.19 & 4.53 & $3.07^{\mathrm{a}}$ & 3.64 & $90.69^{\mathrm{ab}}$ & $85.87^{a}$ & $4.66^{\mathrm{b}}$ & 16.00 \\
\hline 4 & 1 & 0.6 & 1.48 & 4.83 & $2.72^{\mathrm{b}}$ & 3.91 & $91.40^{\mathrm{a}}$ & $87.22^{\mathrm{a}}$ & $4.40^{\mathrm{b}}$ & 13.58 \\
\hline SEM & & & 0.09 & 0.24 & 0.09 & 0.34 & 0.54 & 1.18 & 0.35 & 0.75 \\
\hline \multicolumn{11}{|c|}{ Cr main effect } \\
\hline 0 & & & 1.22 & 4.45 & 2.94 & 3.56 & 90.22 & 83.64 & 5.39 & $15.54^{\circ}$ \\
\hline 1 & & & 1.38 & 4.68 & 2.76 & 3.72 & 91.66 & 87.11 & 4.46 & $14.00^{\mathrm{b}}$ \\
\hline SEM & & & 0.10 & 0.01 & 0.13 & 0.08 & 0.55 & 1.60 & 0.51 & 0.62 \\
\hline \multicolumn{11}{|c|}{ Se main effect } \\
\hline 0 & & & 1.26 & 4.43 & 2.80 & 3.50 & 90.84 & 84.21 & 5.32 & 14.75 \\
\hline 0.6 & & & 1.33 & 4.70 & 2.90 & 3.78 & 90.05 & 86.55 & 4.53 & 14.79 \\
\hline SEM & & & 0.10 & 0.01 & 0.13 & 0.08 & 0.55 & 1.60 & 0.51 & 0.62 \\
\hline \multicolumn{11}{|c|}{ Statistical significance } \\
\hline Cr Effect & & & NS & NS & * & NS & $\star \star$ & * & $\star \star *$ & * \\
\hline Se Effect & & & NS & NS & NS & NS & * & * & $\star \star$ & NS \\
\hline $\mathrm{Cr} \times$ Se inte & action & & NS & NS & * & NS & * & * & * & NS \\
\hline \multicolumn{11}{|c|}{$\begin{array}{l}\text { 1. EV: ejaculate volume, MM: mass motility by } 0-5 \text { score, Conc: sperm concentration, TES: } \\
\text { total sperm per ejaculate, Viab: viability, MI: membrane integrity, TA: total abnormality, RT: } \\
\text { ram reaction time to stimulus as measure of libido. SEM: Standard error of means. Data analyzed } \\
\text { as } 2 \times 2 \text { factorial design. Different superscripts within the columns shows the difference among means in } \\
\text { each group }(P \leq 0.05) .{ }^{\star \star \star} P \leq 0.001 ;{ }^{* \star} P \leq 0.01 ;{ }^{*} P \leq 0.05 \text {; NS not significant. }\end{array}$} \\
\hline
\end{tabular}


Table 5

Effect of organic selenium alone or combined with organic chromium on CASA detected sperm kinematicFeatures and motion characteristics in Mehraban ram 1.

\begin{tabular}{|c|c|c|c|c|c|c|c|c|c|c|c|c|c|}
\hline Treats & $\begin{array}{l}\mathrm{Cr} \\
\mathrm{mg} / \mathrm{d}\end{array}$ & $\begin{array}{l}\mathrm{Se} \\
\mathrm{mg} / \mathrm{d}\end{array}$ & $\begin{array}{l}\text { TM, } \\
\%\end{array}$ & $\begin{array}{l}\text { FPM, } \\
\%\end{array}$ & $\begin{array}{l}\text { VSL, } \\
\mu \mathrm{m} / \mathrm{s}\end{array}$ & $\begin{array}{l}\text { VCL, } \\
\mu \mathrm{m} / \mathrm{s}\end{array}$ & $\begin{array}{l}\text { VAP, } \\
\mu \mathrm{m} / \mathrm{s}\end{array}$ & $\begin{array}{l}\text { ALH, } \\
\%\end{array}$ & $\begin{array}{l}\text { STR, } \\
\%\end{array}$ & $\begin{array}{l}\text { LIN, } \\
\%\end{array}$ & $\begin{array}{l}\text { WOB, } \\
\%\end{array}$ & $\begin{array}{l}B C F \\
\mathrm{~Hz}\end{array}$ & MAD, \\
\hline 1 (Control) & 0 & 0 & 88.03 & 42.43 & 52.30 & $165.80^{\mathrm{ab}}$ & 76.37 & 2.76 & 67.13 & 31.03 & 43.38 & 19.28 & 52.68 \\
\hline 2 & 1 & 0 & 88.71 & 55.45 & 64.72 & $176.12^{\mathrm{a}}$ & 86.66 & 3.15 & 70.96 & 36.14 & 47.28 & 17.84 & 51.92 \\
\hline 3 & 0 & 0.6 & 89.07 & 50.11 & 61.52 & $187.20^{\mathrm{a}}$ & 89.42 & 3.13 & 70.26 & 33.53 & 45.33 & 20.63 & 51.95 \\
\hline 4 & 1 & 0.6 & 87.59 & 51.19 & 54.33 & $151.24^{\mathrm{b}}$ & 75.04 & 2.55 & 68.71 & 34.29 & 44.57 & 19.65 & 52.80 \\
\hline SEM & & & 1.37 & 4.27 & 4.77 & 8.02 & 6.20 & 0.22 & 2.42 & 2.13 & 1.75 & 0.96 & 0.65 \\
\hline \multicolumn{14}{|c|}{ Cr main effect } \\
\hline 0 & & & 88.55 & 46.27 & 56.91 & 176.50 & 82.90 & 2.95 & 67.92 & 32.28 & 44.35 & 19.95 & 52.32 \\
\hline 1 & & & 88.15 & 53.32 & 59.53 & 163.68 & 80.86 & 2.85 & 70.61 & 35.22 & 45.92 & 18.69 & 52.36 \\
\hline SEM & & & 0.76 & 4.22 & 6.93 & 16.36 & 2.13 & 0.34 & 1.90 & 2.07 & 1.11 & 0.13 & 0.56 \\
\hline \multicolumn{14}{|c|}{ Se main effect } \\
\hline 0 & & & 88.37 & 48.94 & 58.51 & 170.96 & 81.52 & 2.95 & 69.77 & 34.39 & 45.23 & 18.56 & 52.30 \\
\hline 0.6 & & & 88.33 & 50.65 & 57.93 & 169.22 & 82.24 & 2.84 & 68.76 & 33.10 & 44.98 & 20.09 & 52.37 \\
\hline SEM & & & 0.76 & 4.22 & 6.93 & 16.36 & 2.13 & 0.34 & 1.90 & 2.07 & 1.11 & 0.13 & 0.56 \\
\hline \multicolumn{14}{|l|}{$P$ value } \\
\hline Cr Effect & & & NS & NS & NS & NS & NS & NS & NS & NS & NS & NS & NS \\
\hline Se Effect & & & NS & NS & NS & NS & NS & NS & NS & NS & NS & NS & NS \\
\hline $\mathrm{Cr} \times \mathrm{Se}$ inter & ction & & NS & NS & * & $\star \star$ & NS & * & NS & NS & NS & NS & NS \\
\hline $\begin{array}{l}\text { 1. TM: total } \\
\text { VAP: averag } \\
\text { as the linea } \\
\text { (VAP/VCL } \times \\
\text { mean angul } \\
\text { the differen } \\
{ }^{\star \star} P \leq 0.01 ;\end{array}$ & $\begin{array}{l}\text { potility, } \\
\text { path ve } \\
\text { of the osc } \\
\text { r displa } \\
\text { amons } \\
P \leq 0.0\end{array}$ & $\begin{array}{l}\text { MM: fast } \\
\text { deity, AL } \\
\text { average } \\
\text { lation } m \\
\text { ement (c } \\
\text { means i } \\
\text { NS not }\end{array}$ & $\begin{array}{l}\text { progress } \\
\text { t: amplit } \\
\text { path, LIN } \\
\text { easure o } \\
\text { egrees). } \\
\text { each gr } \\
\text { ignifican }\end{array}$ & $\begin{array}{l}\text { ve motil } \\
\text { de of la } \\
\text { sperm li } \\
\text { the actc } \\
\text { ata ana } \\
\text { up ( } \mathrm{S} \leq\end{array}$ & $\begin{array}{l}y, \text { VSL: } \\
\text { eral heac } \\
\text { earity ( } \\
\text { al path a } \\
\text { yzed as } \\
.05) .{ }^{\star \star *}\end{array}$ & $\begin{array}{l}\text { displacem } \\
\mathrm{SL} / \mathrm{VCL} \times 1 \\
\text { out the ave } \\
\times 2 \text { factoria } \\
\leq 0.001\end{array}$ & $\begin{array}{l}\text { locity, } \\
\text { tt, STR: } \\
\text { 0) as a } \\
\text { age pat }\end{array}$ & $\begin{array}{l}\text { LL: curv } \\
\text { traight } \\
\text { eeasure } \\
\text { BCF: b }\end{array}$ & $\begin{array}{l}\text { inear ve } \\
\text { ess (VS } \\
\text { f a cur } \\
\text { at cros }\end{array}$ & $\begin{array}{l}\text { ocity, } \\
\text { VAP } \times 1 \\
\text { inear } \\
\text { requen }\end{array}$ & $\begin{array}{l}\text { 0) } \\
\text { h. WOB } \\
\text { MAD: }\end{array}$ & wobble & \\
\hline
\end{tabular}


Table 6

Effect of organic selenium alone or combined with organic chromium on plasma antioxidant status in Mehraban rams1

\begin{tabular}{|c|c|c|c|c|c|c|c|c|}
\hline \multirow[t]{2}{*}{ Treatments } & \multirow[t]{2}{*}{$\begin{array}{l}\mathrm{Cr} \\
\mathrm{mg} / \mathrm{d}\end{array}$} & \multirow[t]{2}{*}{$\begin{array}{l}\mathrm{Se} \\
\mathrm{mg} / \mathrm{d}\end{array}$} & \multicolumn{2}{|c|}{$\begin{array}{l}\text { TBARS } \\
\text { ( } \mu \text { mol/ml plasma) }\end{array}$} & \multirow{2}{*}{$\begin{array}{l}\text { Total } \\
\text { time }\end{array}$} & \multicolumn{2}{|c|}{$\begin{array}{l}\text { FRAP } \\
\text { ( } \mu \mathrm{mol} / \mathrm{ml} \text { plasma) }\end{array}$} & \multirow{2}{*}{$\begin{array}{l}\text { Total } \\
\text { time }\end{array}$} \\
\hline & & & 30 & 60 & & 30 & 60 & \\
\hline 1 (Control) & 0 & 0 & $2.74^{\mathrm{a}}$ & $2.48^{a}$ & $2.61^{a}$ & 482.31 & $501.28^{b}$ & $491.79^{b}$ \\
\hline 2 & 1 & 0 & $2.22^{a b}$ & $1.68^{b}$ & $1.67^{b}$ & 544.31 & $607.09^{a}$ & $575.70^{a}$ \\
\hline 3 & 0 & 0.6 & $1.91^{\mathrm{ab}}$ & $1.44^{b}$ & $1.95^{b}$ & 561.82 & $561.25^{a b}$ & $561.54^{a}$ \\
\hline 4 & 1 & 0.6 & $1.44^{b}$ & $1.51^{b}$ & $1.48^{b}$ & 518.40 & $516.54^{b}$ & $517.47^{a b}$ \\
\hline SEM & & & 0.28 & 0.23 & 0.19 & 27.78 & 21.57 & 19.61 \\
\hline \multicolumn{9}{|l|}{ Cr main effect } \\
\hline 0 & & & $2.48^{a}$ & $2.08^{a}$ & $2.28^{a}$ & 513.31 & 554.19 & 533.76 \\
\hline 1 & & & $1.68^{b}$ & $1.48^{b}$ & $1.57^{b}$ & 540.11 & 538.90 & 539.51 \\
\hline SEM & & & 0.20 & 0.17 & 0.13 & 19.64 & 15.25 & 45.24 \\
\hline \multicolumn{9}{|l|}{ Se main effect } \\
\hline 0 & & & 2.32 & 1.96 & 2.14 & 522.06 & 531.28 & 526.67 \\
\hline 0.6 & & & 1.83 & 1.60 & 1.71 & 531.35 & 561.82 & 546.59 \\
\hline SEM & & & 0.19 & 0.17 & 0.13 & 19.64 & 15.25 & 45.24 \\
\hline Cr effect & & & ** & ** & $\star \star \star$ & NS & NS & NS \\
\hline Se effect & & & NS & NS & * & NS & NS & NS \\
\hline $\mathrm{Cr} \times \mathrm{Se}$ interaction & & & NS & NS & NS & * & 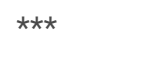 & 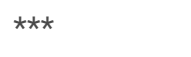 \\
\hline Treat & & & NS & * & 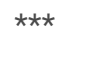 & NS & $\star \star \star$ & * \\
\hline Time & & & & & NS & & & NS \\
\hline Treat $\times$ Time & & & & & NS & & & NS \\
\hline \multicolumn{9}{|c|}{$\begin{array}{l}\text { 1.TBARS: Thiobarbituric acid reactive subs } \\
\text { as } 2 \times 2 \text { factorial design. Different superscr } \\
{ }^{\star \star} P \leq 0.01 ;{ }^{*} P \leq 0.05 \text {; NS not significant. }\end{array}$} \\
\hline
\end{tabular}

Table 7. Effect of organic selenium alone or combined with organic chromium on semen biochemical parameters in Mehrban rams on days 30 and 60 of experiment ${ }^{1}$ 


\begin{tabular}{|c|c|c|c|c|c|c|c|c|c|c|c|c|}
\hline Treats & $\begin{array}{l}\mathrm{Cr} \\
\mathrm{mg} / \mathrm{d}\end{array}$ & $\begin{array}{l}\mathrm{Se} \\
\mathrm{mg} / \mathrm{d}\end{array}$ & $\begin{array}{l}\text { Glucose, } \\
\text { mg/dl }\end{array}$ & $\begin{array}{l}\text { TG, } \\
\mathrm{mg} / \mathrm{dl}\end{array}$ & $\begin{array}{l}\text { TC, } \\
\mathrm{mg} / \mathrm{dl}\end{array}$ & $\begin{array}{l}\mathrm{TP}, \\
\mathrm{mg} / \mathrm{dl}\end{array}$ & $\begin{array}{l}\text { Alb, } \\
\mathrm{mg} / \mathrm{dl}\end{array}$ & $\begin{array}{l}\text { ALP, } \\
U / L\end{array}$ & $\begin{array}{l}\text { AST, } \\
\mathrm{U} / \mathrm{L}\end{array}$ & $\begin{array}{l}\text { ALT, } \\
U / L\end{array}$ & $\begin{array}{l}\text { Calcium, } \\
\text { mg/dl }\end{array}$ & $\begin{array}{l}\text { Phosphorus, } \\
\mathrm{mg} / \mathrm{dl}\end{array}$ \\
\hline $\begin{array}{l}1 \\
\text { (Control) }\end{array}$ & 0 & 0 & $10.63^{a}$ & 125.81 & 126.02 & 6.09 & 1.69 & $54.21^{\mathrm{a}}$ & 13.61 & 167.69 & 7.10 & 11.03 \\
\hline 2 & 1 & 0 & $8.97^{\mathrm{a}}$ & 125.32 & 126.81 & 5.99 & 1.92 & $48.38^{c}$ & 13.36 & 168.30 & 7.12 & $10 . .89$ \\
\hline 3 & 0 & 0.6 & $9.09^{b}$ & 123.95 & 126.04 & 5.80 & 1.89 & $53.05^{\mathrm{ab}}$ & 13.39 & 168.86 & 6.78 & 11.21 \\
\hline 4 & 1 & 0.6 & $7.48^{\mathrm{c}}$ & 122.82 & 127.72 & 6.08 & 1.74 & $49.33^{b c}$ & 12.72 & 164.97 & 6.92 & 11.51 \\
\hline SEM & & & 0.42 & 1.38 & 1.10 & 0.25 & 0.08 & 1.44 & 0.65 & 2.87 & 0.17 & 0.32 \\
\hline \multicolumn{13}{|c|}{ Cr main effect } \\
\hline 0 & & & $9.86^{\mathrm{a}}$ & 124.88 & 126.02 & 6.04 & 1.79 & $53.63^{a}$ & 13.50 & 168.27 & 7.10 & 10.96 \\
\hline 1 & & & $8.22^{\mathrm{b}}$ & 124.07 & 127.27 & 5.74 & 1.83 & $48.84^{b}$ & 13.04 & 166.63 & 6.84 & 11.36 \\
\hline SEM & & & 0.46 & 0.92 & 0.28 & 0.17 & 0.06 & 0.76 & 0.45 & 1.93 & 0.06 & 0.15 \\
\hline \multicolumn{13}{|c|}{ Se main effect } \\
\hline 0 & & & $9.80^{\mathrm{a}}$ & 125.57 & 126.42 & 6.04 & 1.80 & 51.28 & 13.48 & 167.99 & 6.93 & 11.12 \\
\hline 0.6 & & & $8.28^{\mathrm{b}}$ & 123.39 & 126.87 & 5.94 & 1.80 & 51.19 & 13.05 & 166.91 & 7.02 & 11.20 \\
\hline SEM & & & 0.46 & 0.92 & 0.28 & 0.17 & 0.06 & 0.76 & 0.45 & 1.93 & 0.06 & 0.15 \\
\hline \multicolumn{13}{|l|}{$P$ value } \\
\hline Cr Effect & & & $\star \star$ & NS & NS & NS & NS & $\star \star \star ~$ & NS & NS & NS & NS \\
\hline Se Effect & & & * & NS & NS & NS & NS & NS & NS & NS & NS & NS \\
\hline $\mathrm{Cr} \times$ Se int & raction & & NS & NS & NS & NS & * & NS & NS & NS & NS & NS \\
\hline Treat & & & $\star \star$ & NS & NS & NS & NS & * & NS & NS & NS & NS \\
\hline Time & & & NS & NS & NS & NS & $\star \star$ & NS & NS & NS & NS & NS \\
\hline Treat $\times$ Tre & at & & $\star \star$ & NS & NS & NS & NS & NS & NS & NS & NS & NS \\
\hline $\begin{array}{l}\text { TG: triglyc } \\
\text { AST: aspa } \\
\text { Different s } \\
\text { means in } €\end{array}$ & $\begin{array}{l}\text { rides, Tc } \\
\text { tate ami } \\
\text { uperscrip } \\
\text { ach grou }\end{array}$ & $\begin{array}{l}\text { total cl } \\
\text { otransf } \\
\text { s within } \\
(P \leq 0\end{array}$ & $\begin{array}{l}\text { lesterol, Th } \\
\text { rase, ALT: a } \\
\text { he column } \\
\text { 5). }\end{array}$ & $\begin{array}{l}\text { : total pro } \\
\text { anine am } \\
\text { shows th }\end{array}$ & $\begin{array}{l}\text { ein, Alb: } \\
\text { notransfe } \\
\text { differen }\end{array}$ & $\begin{array}{l}\text { bumin, A } \\
\text { ase, SEM } \\
\text { e among }\end{array}$ & $\begin{array}{l}\text { P: alkali } \\
\text { Standar }\end{array}$ & $\begin{array}{l}\text { e phosph } \\
\text { error of } n\end{array}$ & $\begin{array}{l}\text { ase, } \\
\text { eans. }\end{array}$ & & & \\
\hline
\end{tabular}

